OPEN ACCESS

Edited by:

Katharina F. Kubatzky,

University Hospital Heidelberg,

Germany

Reviewed by:

Xingmin Sun,

Tufts University Cummings School of

Veterinary Medicine, USA

Masataka Oda,

Niigata University, Japan

${ }^{*}$ Correspondence: Holger Barth,

Institute of Pharmacology and Toxicology, University of Ulm Medical

Center, Albert-Einstein-Allee 11,

Ulm D-89081, Germany

holger.barth@uni-ulm.de

Specialty section:

This article was submitted to Microbial Immunology, a section of the journal Frontiers in Immunology

Received: 19 May 2015 Accepted: 17 June 2015

Published: 30 June 2015

Citation:

Barth H, Fischer S, Möglich A and Förtsch C (2015) Clostridial C3 toxins target monocytes/macrophages and modulate their functions.

Front. Immunol. 6:339. doi: 10.3389/fimmu.2015.00339

\section{Clostridial C3 toxins target monocytes/macrophages and modulate their functions}

\author{
Holger Barth ${ }^{1 *}$, Stephan Fischer ${ }^{1,2}$, Amelie Möglich $^{1}$ and Christina Förtsch ${ }^{1}$ \\ ${ }^{1}$ Institute of Pharmacology and Toxicology, University of Ulm Medical Center, Ulm, Germany, ${ }^{2}$ Institute of Organic Chemistry \\ III, University of Ulm, Ulm, Germany
}

The C3 enzymes from Clostridium (C.) botulinum (C3bot) and Clostridium limosum (C3lim) are single chain protein toxins of about $25 \mathrm{kDa}$ that mono-ADP-ribosylate Rho- $A,-B$, and $-C$ in the cytosol of mammalian cells. We discovered that both C3 proteins are selectively internalized into the cytosol of monocytes and macrophages by an endocytotic mechanism, comparable to bacterial AB-type toxins, while they are not efficiently taken up into the cytosol of other cell types including epithelial cells and fibroblasts. C3-treatment results in disturbed macrophage functions, such as migration and phagocytosis, suggesting a novel function of clostridial C3 toxins as virulence factors, which selectively interfere with these immune cells. Moreover, enzymatic inactive C3 protein serves as a transport system to selectively deliver pharmacologically active molecules into the cytosol of monocytes/macrophages without damaging these cells. This review addresses also the generation of C3-based molecular tools for experimental macrophage pharmacology and cell biology as well as the exploitation of C3 for development of novel therapeutic strategies against monocyte/ macrophage-associated diseases.

Keywords: C3, Rho, macrophage, cellular uptake, targeted drug delivery

\section{Introduction: Bacterial C3 Proteins}

Various Gram-positive bacteria produce and secrete $\mathrm{C} 3$ proteins $(\sim 25 \mathrm{kDa}, \mathrm{pI}>9)$ that selectively mono-ADP-ribosylate the small GTPases Rho-A, -B, and -C. C3 ADP-ribosyltransferases catalyze the covalent transfer of the ADP-ribose group from the cosubstrate NAD onto Asn-41 of Rho (1, 2). In 1987, Aktories and co-workers described the first C3 protein (C3bot), which is produced from Clostridium botulinum $\mathrm{C}$ and D strains $(3,4)$. It became evident that there are two isoforms, C3bot 1 and C3bot 2 with $60 \%$ sequence identity. Further, C3 proteins were identified in Clostridium limosum (C3lim) (5), Bacillus cereus (C3cer) (6), as well as Staphylococcus aureus (C3stau) (7). C3stau alias epithelial differentiation inhibitor (EDIN) includes three isoforms (A, B, and C), which share $\sim 35 \%$ sequence identity to C3bot1 and ADP-ribosylates RhoE in addition to Rho-A, $-B$, and $-\mathrm{C}(7)$.

The pathophysiological role of the clostridial C3 proteins is not clear so far, but it was suggested that C3stau might play a role as virulence factor, since more C3stau-producing S. aureus were isolated from patients with impetigo, diabetic foot ulcers, and other skin infections than from healthy carriers (8-11). In contrast to the clostridia, S. aureus enters mammalian cells and releases C3stau into the host cell cytosol, where the C3stau-catalyzed ADP-ribosylation of Rho results 
in reorganization of the actin cytoskeleton (12). In tissues, this mode of action causes disruption of cell-cell contacts and barrier functions, which allows the dissemination of $S$. aureus through the disturbed tissue barriers into deeper tissues, as already demonstrated in animal models $(12,13)$. Moreover, in endothelial cells, the C3stau-mediated reorganization of the actin cytoskeleton results in the formation of large transendothelial channels, so-called macroapertures (TEMs) (14-16), which increase the endothelial permeability and facilitate the dissemination of $S$. aureus from blood to deeper tissue layers.

\section{C3 Enzymes Mono-ADP-Ribosylate Rho and Inhibit Rho Signaling}

Up to date, C3 enzymes represent the only known specific Rho inhibitors and were widely used in biochemistry, cell biology, and experimental pharmacology as highly valuable molecular tools to investigate the role of Rho-signaling in vitro and in living cells $(17,18)$. However, it soon became evident that $\mathrm{C} 3$ proteins are not efficiently taken up into the cytosol of the tested cell types including epithelial cells and fibroblasts and it was suggested that C3 proteins might be exoenzymes rather than typical exotoxins, which become internalized only by non-specific mechanisms, such as pinocytosis, when cultured cells were treated for long incubation periods $(>24 \mathrm{~h})$ with high C3 concentrations $(>10 \mu \mathrm{g} / \mathrm{ml})$ in the medium (19). Therefore, C3 proteins were introduced into the cytosol of cells by artificial methods including microinjection, transfection, or by the use of molecular transporters like cellpenetrating peptides, viruses, or portions of bacterial AB-toxins $(18,20)$.

In line with the observation of their very limited and nonspecific uptake in the tested cell types, no binding and translocation subunit was found in the $\mathrm{C} 3$ proteins, which could mediate their uptake into the host cell cytosol. Structure analysis of C3bot and C3stau revealed that these proteins consist of a single enzyme domain with a catalytic core containing the conserved NAD binding site and a catalytic pocket with an $\alpha$-helix bent lying over two antiparallel $\beta$-sheets, which form a central cleft $(21,22)$ and show high structure similarity with the catalytic domains of binary actin-ADP-ribosylating toxins (18, 22, 23). Moreover, like the binary actin-ADP-ribosylating toxins, C3 enzymes contain the highly conserved amino acids, which were also identified in other ADP-ribosyltransferases: the STS-motif 174Ser-Thr-Ser176, which is flanked by Arg128 and Glu214 (22) and the "catalytic glutamate" Glu214, which plays a central role in the covalent transfer of ADP-ribose onto Asn41 of Rho. Furthermore, the binary actin ADP-ribosylating toxins and the $\mathrm{C} 3$ enzymes contain the so-called ADP-ribosylating toxin turn-turn (ARTT) motif, two adjacent protruding turns, which play a role for the toxin-specific recognition of actin or Rho: at position 212 in turn 2, the Rho-modifying C3 enzymes have a Gln residue, the actin-ADP-ribosylating toxins a Glu residue (22, 24). The precise molecular mechanisms of the ADP-ribosylation as well as the function of the individual amino acid residues of the ADP-ribosyltransferases is described in more detail in highly acknowledged reviews $(18,25)$.
Besides the Rho ADP-ribosylation, C3 acts on RalA, a member of the Ras GTPase family, in a non-enzymatic manner independent from its ADP-ribosyltransferase activity. C3 directly binds to RalA (6), which keeps RalA in its inactive GDP-bound conformation and prevents the activation of downstream RalA effectors $(26,27)$. However, the cellular consequences of this C3-RalA interaction are not known so far.

\section{Molecular and Cellular Consequences of the C3-Catalyzed Rho ADP-Ribosylation}

The C3 enzymes specifically mono-ADP-ribosylate the isoforms Rho A, -B, and -C at Asn-41 and prefer Rho-GDP as substrate $(28,29)$ because in this structure, Asn41 is accessible to C3 $(30)$. As a consequence, the ADP-ribosylated Rho-GDP binds more efficiently to GDI, which traps Rho in the Rho-GDI complexes in the cytosol [Ref. (31), for review on Rho regulation see Ref. (32)]. This prevents the translocation of cytosolic Rho to the cytoplasmic membrane and consequently its activation to Rho-GTP and the subsequent activation of the various cellular Rho-effector molecules $(33,34)$. This disturbed Rho signaling is the reason underlying most of the cellular effects observed after treatment of cells with C3. However, it should be kept in mind that due to the very limited cellular uptake of $\mathrm{C} 3$ proteins, all the experiments with cultured cells or tissues summarized below, were performed either by incubating the cells for a long time with high concentrations of $\mathrm{C} 3$ protein, or by introducing $\mathrm{C} 3$ into the cytosol via artificial approaches.

In 1989, Chardin and co-workers described that C3-treatment of Vero cells results in a characteristic change of the cell morphology with cell-rounding, formation of long protrusions, and reorganization of the actin filaments (35). Importantly, this was the first evidence that Rho signaling might be associated with the structure of actin filaments in mammalian cells. Due to its substrate specificity, C3 proved to be a very useful tool to unravel the role of Rho for the organization of the actin cytoskeleton and for actindependent processes in various eukaryotic cell types. It was found that C3-treatment inhibited endocytosis, exocytosis, cytokinesis, cell cycle progression, modulated the neuronal plasticity, and induced apoptosis $(25,36,37)$. In leukocytes, the C3-catalyzed Rho-inhibition inhibited migration (38-40), adhesion (41, 42), and phagocytosis (43), suggesting a pathophysiological role of C3 proteins toward such immune cells. However, the role of C3 proteins remained unclear, mainly because of their limited cellular uptake.

The increasing knowledge on the C3-mediated effects resulted in the pharmacological exploitation of $\mathrm{C} 3$ for novel therapeutic strategies. The C3-catalyzed inhibition of Rho signaling has protective effects on neurons of the central nervous system because it prevented the ephrin-A5-induced growth cone collapse of such cells in vitro (44). Moreover, independent of its ADP-ribosyltransferase activity, C3bot - but not C3lim - exhibits neurotrophic effects on cells of the central nerve system, as demonstrated for murine hippocampal neurons (45-48), but not on cells of the peripheral nerve system (49). The recombinant cell-permeable C3bot protein BA-210 $\left(\right.$ Cethrin $\left.^{\mathrm{Tw}}\right)$, which acts as Rho inhibitor, became a drug for 
treatment of acute spinal cord injury in men. This Rho-inhibitor showed promising effects after local application in pre-clinical animal studies (50) and is evaluated by the U.S. National Institutes of Health in a phase IIb clinical trial for its efficacy and safety.

\section{Clostridial C3 Toxins Selectively Enter Monocytes/Macrophages and Allow for Targeted Pharmacological Modulation of Rho-Dependent Processes in these Cells}

Based on reported inhibitory effects of $\mathrm{C} 3$ on basic leukocyte functions, a potential pathophysiological role of C3 toward immune cells was suggested and in 2010, Barth and co-workers identified monocytes/macrophages as target cells for C3bot and C3lim (19). It was demonstrated that within short incubation periods (e.g., $3 \mathrm{~h}$ ), comparatively low concentrations of C3bot or C3lim (e.g., $0.5-1 \mu \mathrm{g} / \mathrm{ml}$ ) were efficiently taken up into the cytosol of cultured monocytes and macrophages, such as murine (J774A.1, RAW 264.7) and human cell lines, and primary cultured human macrophages after their differentiation from blood monocytes, while under comparable experimental conditions, no relevant uptake of clostridial C3 toxins into the cytosol of cultured epithelial cells and fibroblasts was observed. Most likely, C3bot and C3lim enter the cytosol of monocytes/macrophages by a specific endocytotic mechanism because their uptake was decreased after pretreatment of cells with bafilomycin A1 $(19,51)$, which inhibits endosomal acidification. Taken together, these results suggest that the clostridial C3 proteins might act on monocytes/macrophages like fully functional bacterial exotoxins but the precise molecular mechanisms underlying their cellular uptake and intracellular transport are not known so far. However, Just and co-workers, who confirmed and extended the studies on the interaction of clostridial C3 proteins with macrophages, got experimental evidence that C3 binds to proteinaceous structures on J774A.1 macrophages, which exhibit significantly more C3-binding sites compared to other cell types (52). Moreover, vimentin might be involved in the uptake of C3 protein into macrophages (52).

The C3-treatment of macrophages resulted in characteristic morphological changes due to a reorganization of the actin cytoskeleton (19), as shown in Figures 1A,B. Importantly, this effect strictly depended on the C3-catalyzed ADP-ribosylation of Rho in the cytosol of the macrophages as enzymatically inactive C3botE174Q had no effect on cell morphology but was taken up into macrophages comparable to wild-type C3 (19). The C3-mediated impairment of Rho-signaling inhibits essential macrophage functions, such as phagocytosis (53) and migration [Ref. (54), Figure 1C], suggesting an immunosuppressive mode of action of the clostridial C3 proteins.

Moreover, treatment of RAW264.7 macrophages with recombinant C3bot and C3lim proteins prevented their differentiation to osteoclast-like cells and C3-treatment of already differentiated and fully active osteoclast-like cells, which can be considered as "specialized macrophages," inhibited their resorbing activity in vitro (55). Interestingly, a recombinant C3lim fusion protein (C2IN-C3lim), which contains C2IN, an enzymatically inactive portion of $\mathrm{C} 2 \mathrm{I}$, the enzyme component of the binary actin ADPribosylating C. botulinum $\mathrm{C} 2$ toxin (56), was much more efficient

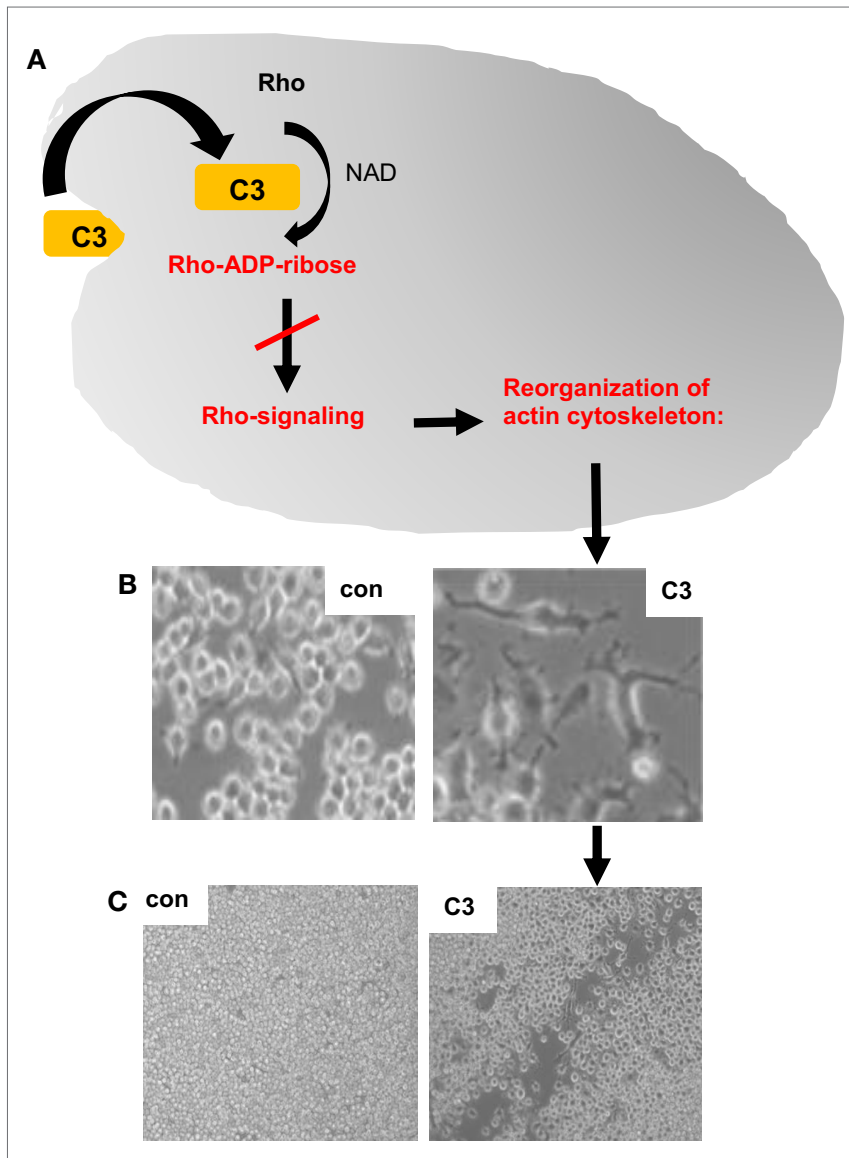

FIGURE 1 | Effects of clostridial C3 toxin on macrophages. The uptake of clostridial C3 toxin into the cytosol of macrophages causes the C3-catalyzed ADP-ribosylation of Rho and inhibition of Rho signaling, which results in a reorganization of the actin cytoskeleton [schematically depicted in (A)], a dramatic change of the cell morphology (B) and an inhibition of the migration of cultured macrophages, as shown by the scratch test experiment (C). NAD, nicotinamide adenine dinucleotide; con, untreated J774A.1 macrophages, which were grown for $24 \mathrm{~h}$ after the removal of a portion of the cells by a scratch; C3, J774A.1 cells treated for $24 \mathrm{~h}$ with $300 \mathrm{nM}$ C3bot1 after removal of some cells by a scratch. After treatment with C3bot1, the scratch remains open, indicating less macrophage migration of c3-treated macrophages compared to untreated control cells.

then C3bot and C3lim regarding the targeted pharmacological manipulation of osteoclast formation and activity in vitro (55); most likely, this fusion protein is more efficiently internalized into the macrophages then the wild-type $\mathrm{C} 3$ proteins. Taken together, the recombinant $\mathrm{C} 3$ proteins and fusion proteins represent attractive candidates for targeted pharmacological manipulation of osteoclast formation and activity with great potential for the development of novel anti-resorptive therapies in low bone mass diseases, such as osteoporosis.

\section{Clostridial C3 Proteins for Targeted Monocyte/ Macrophage-Selective Drug Delivery}

Due to the fact that comparatively low concentrations of the clostridial C3 proteins are much more efficiently taken up into monocytes and macrophages then in other cell types, such as 
epithelial cells or fibroblasts, enzymatically inactive C3 protein should represent an optimal transporter for the targeted delivery of pharmacologically active (macro)molecules including therapeutic proteins and peptides into the cytosol of monocytes/ macrophages. Therefore, Barth and co-workers developed and characterized novel transport systems based on enzymatically inactive C3bot1E174Q (57), which is efficiently taken up into monocytes/macrophages (19), but does not exhibit adverse effects or induces macrophage activation (51). For proof-ofconcept, a pharmacologically active enzyme, namely, the actin ADP-ribosylating C. botulinum C2I, was genetically fused as a reporter enzyme to $\mathrm{C} 3$ botE174Q and the uptake of the resulting recombinant C3botE174Q-C2I (see Figure 2A) into the cytosol of cultured macrophages was investigated. Indeed, C3bot1E174Q served for delivery of C2I into the cytosol of macrophage-like cell lines and primary human macrophages derived from blood monocytes. Incubation with C3bot1E174Q-C2I in the culture medium resulted in the ADP-ribosylation of actin in the cytosol of the macrophages and consequently in the depolymerization of F-actin (51), a clear indication that enzymatically active C2I reached the cytosol. Importantly, C3bot1E174Q-C2I had no effect on epithelial cells or fibroblasts, indicating the cell-type selectivity of this fusion toxin (51). Moreover, an application of C2I alone into the medium had no effect on the macrophages because C2I is not taken up into cells. In conclusion, enzymatically inactive C3 protein was established as a novel macrophage/monocyte-selective transport system. The generated recombinant actin-inhibitor C3bot1E174Q-C2I can serve for the targeted modulation of actin-dependent processes in monocytes and macrophages, such as the inhibition of migration and phagocytosis in the context of macrophage-associated diseases.

Prompted by this first successful exploitation of C3 for protein delivery, novel modular transporters based on biotin/streptavidin technology were developed $(58,59)$, as depicted in Figure 2B. Here, the C3botE174Q moiety mediates the specific transport of streptavidin into the cytosol of monocytes/macrophages. Streptavidin was either coupled to C3botE174Q by chemical crosslinking (59) or by genetic fusion (58) and serves as a delivery platform for biotin-labeled cargo molecules, which are then released in the host cell cytosol to elicit their pharmacological effects, as demonstrated for the enzymatic domain DTA of diphtheria toxin (58), which triggers cell death by inactivating the elongation factor EF-2, which is essential for protein biosynthesis (60) (see Figure 2B). In conclusion, enzymatically inactive $\mathrm{C} 3$ protein serves as a transport system for delivery of "foreign" proteins including pharmacologically active enzymes into the cytosol of cultured monocytes/macrophages.

\section{Conclusion}

Recombinant C3 toxins and C3 fusion toxins proved to represent valuable tools to modulate Rho- and actin-associated cell functions in monocytes and macrophages and the novel C3-based transport systems are attractive carriers for targeted drug delivery into these cells. The detailed characterization of the cellular uptake and the cellular consequences of the C3-based molecules in clinically

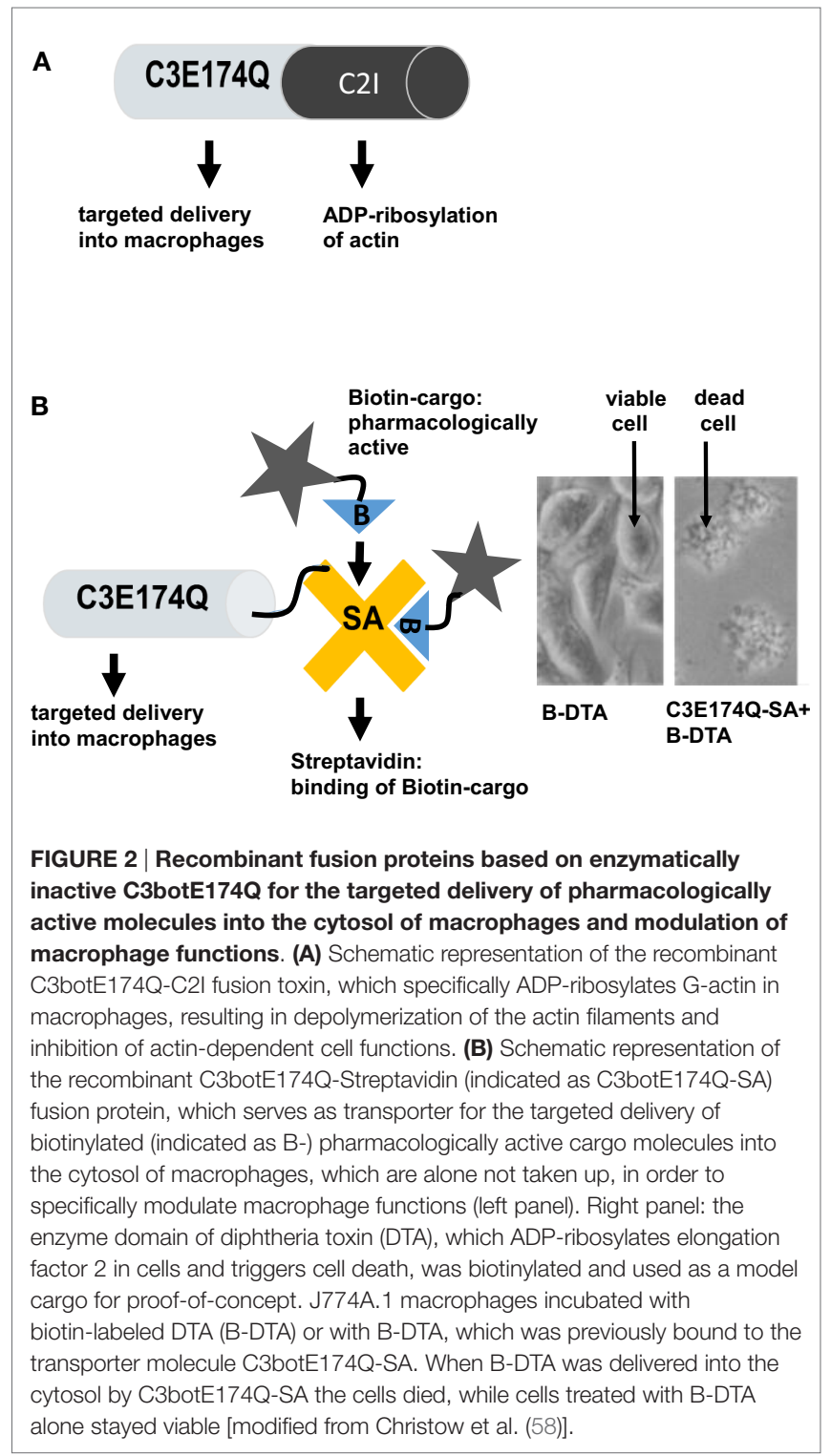

relevant animal models, for example, after local application of C3 molecules coupled to tailored supramolecular nanocarriers $(61,62)$, will show whether the very promising results obtained in vitro and ex vivo can be exploited for the targeted pharmacological modulation of cellular functions in the context of monocyte/ macrophage-associated diseases in vivo, such as inflammation, infection, or low bone mass diseases.

\section{Acknowledgments}

The research underlying parts of this review, which was performed in the laboratory of HB was supported by the Deutsche Forschungsgemeinschaft (SFB1149, project A04), the International Graduate School in Molecular Medicine Ulm (IGradU) and the Medical Faculty of the University of Ulm. SF and AM are members of IGradU. 


\section{References}

1. Aktories K. Bacterial protein toxins that modify host regulatory GTPases. Nat Rev Microbiol (2011) 9:487-98. doi:10.1038/nrmicro2592

2. Ménétrey J, Flatau G, Stura EA, Charbonnier JB, Gas F, Teulon JM, et al. NAD binding induces conformational changes in Rho ADP-ribosylating Clostridium botulinum C3 exoenzyme. J Biol Chem (2002) 277:30950-7. doi:10.1074/jbc. M201844200

3. Aktories K, Weller U, Chatwal GS. Clostridium botulinum type C produces a novel ADP-ribosyltransferase distinct from botulinum C2 toxin. FEBS Lett (1987) 212:109-13. doi:10.1016/0014-5793(87)81566-1

4. Rubin EJ, Gill DM, Boquet P, Popoff MR. Functional modification of a 21-kilodalton G protein when ADP-ribosylated by exoenzyme C3 of Clostridium botulinum. Mol Cell Biol (1988) 8:418-26.

5. Just I, Mohr C, Schallehn G, Menard L, Didsbury JR, Vandekerckhove J, et al. Purification and characterization of an ADP-ribosyltransferase produced by Clostridium limosum. J Biol Chem (1992) 267:10274-80.

6. Wilde C, Vogelsgesang M, Aktories K. Rho-specific Bacillus cereus ADPribosyltransferase C3cer cloning and characterization. Biochemistry (2003) 42:9694-702. doi:10.1021/bi034583b

7. Wilde C, Chhatwal GS, Schmalzing G, Aktories K, Just I. A novel C3-like ADPribosyltransferase from Staphylococcus aureus modifying RhoE and Rnd3. J Biol Chem (2001) 276:9537-42. doi:10.1074/jbc.M011035200

8. Czech A, Yamaguchi T, Bader L, Linder S, Kamisnki K, Sugai M, et al. Prevalence of Rho-inactivating epidermal cell differentiation inhibitor toxins in clinical Staphylococcus aureus isolates. J Infect Dis (2001) 184:785-8. doi:10.1086/ 322983

9. O'Neill AJ, Larsen AR, Skov R, Henriksen AS, Chopra I. Characterization of the epidemic European fusidic acid-resistant impetigo clone of Staphylococcus aureus. J Clin Microbiol (2007) 45:1505-10. doi:10.1128/JCM.01984-06

10. Messad N, Landraud L, Canivet B, Lina G, Richard JL, Sotto A, et al. Distribution of edin in Staphylococcus aureus isolated from diabetic foot ulcers. Clin Microbiol Infect (2013) 19:875-80. doi:10.1111/1469-0691.12084

11. Munro P, Clement R, Lavigne JP, Pulcini C, Lemichez E, Landraud L. High prevalence of edin-C encoding RhoA-targeting toxin in clinical isolates of Staphylococcus aureus. Eur J Clin Microbiol Infect Dis (2011) 30:965-72. doi:10.1007/s10096-011-1181-6

12. Molinari G, Rohde M, Wilde C, Just I, Aktories K, Chhatwal GS. Localization of the C3-like ADP-ribosyltransferase from Staphylococcus aureus during bacterial invasion of mammalian cells. Infect Immun (2006) 74:3673-7. doi:10.1128/ IAI.02013-05

13. Munro P, Benchetrit M, Nahori MA, Stefani C, Clement R, Michiels JF, et al. The Staphylococcus aureus epidermal cell differentiation inhibitor toxin promotes formation of infection foci in a mouse model of bacteremia. Infect Immun (2010) 78:3404-11. doi:10.1128/IAI.00319-10

14. Boyer L, Doye A, Rolando M, Flatau G, Munro P, Gounon P, et al. Induction of transient macroapertures in endothelial cells through RhoA inhibition by Staphylococcus aureus factors. J Cell Biol (2006) 173:809-19. doi:10.1083/ jcb.200509009

15. Lemichez E, Aktories K. Hijacking of Rho GTPases during bacterial infection. Exp Cell Res (2013) 319:2329-36. doi:10.1016/j.yexcr.2013.04.021

16. Maddugoda MP, Stefani C, Gonzalez-Rodriguez D, Saarikangas J, Torrino S, Janel $\mathrm{S}$, et al. cAMP signaling by anthrax edema toxin induces transendothelial cell tunnels, which are resealed by MIM via Arp2/3-driven actin polymerization. Cell Host Microbe (2011) 10:464-74. doi:10.1016/j.chom.2011.09.014

17. Nobes CD, Hall A. Clostridium botulinum C3 exoenzyme and studies on Rho proteins. In: Aktories K, editor. Bacterial Toxins - Tools in Cell Biology and Pharmacology. Weinheim: Chapman \& Hall (1993). p. 71-83.

18. Vogelsgesang M, Pautsch A, Aktories K. C3 exoenzymes, novel insights into structure and action of Rho ADP-ribosylating toxins. Naunyn Schmiedebergs Arch Pharmacol (2007) 374:347-60. doi:10.1007/s00210-006-0113-y

19. Fahrer J, Kuban J, Heine K, Rupps G, Kaiser E, Felder E, et al. Selective and specific internalization of clostridial C3 ADP-ribosyltransferases into the cytosol of macrophages. Cell Microbiol (2010) 12:233-47. doi:10.1111/j.1462-5822.2009.01393.x

20. Barth H, Blöcker D, Aktories K. The uptake machinery of clostridial actin ADPribosylating toxins - a cell delivery system for fusion proteins and polypeptide drugs. Naunyn Schmiedebergs Arch Pharmacol (2002) 366:501-12. doi:10.1007/ s00210-002-0626-y
21. Evans HR, Sutton JM, Holloway DE, Ayriss J, Shone CC, Acharya KR. The crystal structure of C3stau2 from Staphylococcus aureus and its complex with NAD. J Biol Chem (2003) 278:45924-30. doi:10.1074/jbc.M307719200

22. Han S, Arvai AS, Clancy SB, Tainer JA. Crystal structure and novel recognition motif of Rho-ADP-ribosylating exoenzyme from Clostridium botulinum: structural insights for recognition specificity and catalysis. J Mol Biol (2001) 305:95-107. doi:10.1006/jmbi.2000.4292

23. Tsuge H, Nagahama M, Nishimura H, Hisatsune J, Sakaguchi $Y$, Itogawa $Y$, et al. Crystal structure and site-directed mutagenesis of enzymatic components from Clostridium perfringens iota-toxin. J Mol Biol (2003) 325:471-83. doi:10.1016/ S0022-2836(02)01247-0

24. Han S, Craig JA, Putnam CD, Carozzi NB, Tainer JA. Evolution and mechanism from structures of an ADP-ribosylating toxin and NAD complex. Nat Struct Biol (1999) 6:932-6. doi:10.1038/13300

25. Aktories K, Wilde C, Vogelsgesang M. Rho-modifying C3-like ADPribosyltransferases. Rev Physiol Biochem Pharmacol (2004) 152:1-22. doi:10.1007/ s10254-004-0034-4

26. Holbourn KP, Sutton JM, Evans HR, Shone CC, Acharya KR. Molecular recognition of an ADP-ribosylating Clostridium botulinum C3 exoenzyme by RalA GTPase. Proc Natl Acad Sci U S A (2005) 102:5357-62. doi:10.1073/pnas.0501525102

27. Pautsch A, Vogelsgesang M, Tränkle J, Herrmann C, Aktories K. Crystal structure of the C3bot-RalA complex reveals a novel type of action of a bacterial exoenzyme. EMBO J (2005) 24:3670-80. doi:10.1038/sj.emboj.7600813

28. Aktories K, Frevert J. ADP-ribosylation of a 21-24 kDa eukaryotic protein(s) by $\mathrm{C} 3$, a novel botulinum ADP-ribosyltransferase, is regulated by guanine nucleotide. Biochem J (1987) 247:363-8.

29. Habermann B, Mohr C, Just I, Aktories K. ADP-ribosylation and de-ADPribosylation of the Rho protein by Clostridium botulinum exoenzyme C3. Regulation by EDTA, guanine nucleotides and pH. Biochim Biophys Acta (1991) 1077:253-8. doi:10.1016/0167-4838(91)90537-A

30. Wei Y, Zhang Y, Derewenda U, Liu X, Minor W, Nakamoto RK, et al. Crystal structure of RhoA-GDP and its functional implications. Nat Struct Biol (1997) 4:699-703. doi:10.1038/nsb0997-699

31. Fujihara H, Walker LA, Gong MC, Lemichez E, Boquet P, Somlyo AV, et al Inhibition of RhoA translocation and calcium sensitization by in vivo ADPribosylation with the chimeric toxin DC3B. Mol Biol Cell (1997) 8:2437-47. doi: $10.1091 / \mathrm{mbc} .8 .12 .2437$

32. Etienne-Manneville S, Hall A. Rho GTPases in cell biology. Nature (2002) 420:629-35. doi:10.1038/nature01148

33. Sehr P, Joseph G, Genth H, Just I, Pick E, Aktories K. Glucosylation and ADP ribosylation of rho proteins: effects on nucleotide binding, GTPase activity, and effector coupling. Biochemistry (1998) 37:5296-304. doi:10.1021/bi972592c

34. Genth H, Gerhard R, Maeda A, Amano M, Kaibuchi K, Aktories K, et al. Entrapment of Rho ADP-ribosylated by Clostridium botulinum C3 exoenzyme in the Rho-guanine nucleotide dissociation inhibitor-1 complex. J Biol Chem (2003) 278:28523-7. doi:10.1074/jbc.M301915200

35. Chardin P, Boquet P, Madaule P, Popoff MR, Rubin EJ, Gill DM. The mammalian $\mathrm{G}$ protein rho $\mathrm{C}$ is $\mathrm{ADP}$-ribosylated by Clostridium botulinum exoenzyme $\mathrm{C} 3$ and affects actin microfilament in vero cells. EMBO J (1989) 8:1087-92.

36. Aktories K, Barth H, Just I. Clostridium botulinum C3 exoenzyme and C3-like transferases. In: Aktories K, Just I, editors. Bacterial Protein Toxins. Berlin: Springer (2000). p. 207-33.

37. Nusrat A, Giry M, Turner JR, Colgan SP, Parkos CA, Carnes D, et al. Rho protein regulates tight junctions and perijunctional actin organization in polarized epithelia. Proc Natl Acad Sci U S A (1995) 92:10629-33. doi:10.1073/pnas.92.23.10629

38. Worthylake RA, Lemoine S, Watson JM, Burridge K. RhoA is required for monocyte tail retraction during transendothelial migration. J Cell Biol (2001) 154:147-60. doi:10.1083/jcb.200103048

39. Aepfelbacher M, Essler M, Huber E, Czech A, Weber PC. Rho is a negative regulator of human monocyte spreading. J Immunol (1996) 157:5070-5.

40. Verschueren H, De Baetselier P, De Braekeleer J, Dewit J, Aktories K, Just I. ADPribosylation of Rho-proteins with botulinum C3 exoenzyme inhibits invasion and shape changes of T-lymphoma cells. Eur J Cell Biol (1997) 73:182-7.

41. Laudanna C, Campbell JJ, Butcher EC. Role of Rho in chemoattractant-activated leukocyte adhesion through integrins. Science (1996) 271:981-3. doi:10.1126/ science.271.5251.981

42. Liu L, Schwartz BR, Lin N, Winn RK, Harlan JM. Requirement for RhoA kinase activation in leukocyte de-adhesion. J Immunol (2002) 169:2330-6. doi:10.4049/ jimmunol.169.5.2330 
43. Caron E, Hall A. Identification of two distinct mechanisms of phagocytosis controlled by different Rho GTPases. Science (1998) 282:1717-21. doi:10.1126/ science.282.5394.1717

44. Wahl S, Barth H, Ciossek T, Aktories K, Müller BK. Ephrin-A5 induces collapse of growth cones by activating Rho and Rho kinase. J Cell Biol (2000) 149:263-70. doi:10.1083/jcb.149.2.263

45. Ahnert-Hilger G, Höltje M, Grosse G, Pickert G, Mucke C, NixdorfBergweiler B, et al. Differential effects of Rho GTPases on axonal and dendritic development in hippocampal neurons. J Neurochem (2004) 90:9-18. doi:10.1111/j.1471-4159.2004.02475.x

46. Höltje M, Djalali S, Hofmann F, Münster-Wandowski A, Hendrix S, Boato F, et al. A 29-amino acid fragment of Clostridium botulinum C3 protein enhances neuronal outgrowth, connectivity, and reinnervation. FASEB J (2009) 23:1115-26. doi:10.1096/fj.08-116855

47. Boato F, Hendrix S, Huelsenbeck SC, Hofmann F, Grosse G, Djalali S, et al. C3 peptide enhances recovery from spinal cord injury by improved regenerative growth of descending fiber tracts. J Cell Sci (2010) 123:1652-62. doi:10.1242/jcs.066050

48. Loske P, Boato F, Hendrix S, Piepgras J, Just I, Ahnert-Hilger G, et al. Minimal essential length of Clostridium botulinum C3 peptides to enhance neuronal regenerative growth and connectivity in a non-enzymatic mode. J Neurochem (2012) 120:1084-96. doi:10.1111/j.1471-4159.2012.07657.x

49. Auer M, Allodi I, Barham M, Udina E, Neiss WF, Navarro X, et al. C3 exoenzyme lacks effects on peripheral axon regeneration in vivo. J Peripher Nerv Syst (2013) 18:30-6. doi:10.1111/jns5.12004

50. Fehlings MG, Theodore N, Harrop J, Maurais G, Kuntz C, Shaffrey CI, et al. A phase I/IIa clinical trial of a recombinant Rho protein antagonist in acute spinal cord injury. J Neurotrauma (2011) 28:787-96. doi:10.1089/neu.2011.1765

51. Dmochewitz L, Förtsch C, Zwerger C, Väth M, Felder E, Huber-Lang M, et al. A recombinant fusion toxin based on enzymatic inactive C3bot1 selectively targets macrophages. PLoS One (2013) 8:e54517. doi:10.1371/journal.pone.0054517

52. Rohrbeck A, von Elsner L, Hagemann S, Just I. Binding of Clostridium botulinum C3 exoenzyme to intact cells. Naunyn Schmiedebergs Arch Pharmacol (2014) 387:523-32. doi:10.1007/s00210-014-0963-7

53. Park J, Kim JS, Jung KC, Lee HJ, Kim JI, Kim J, et al. Exoenzyme Tat-C3 inhibits association of zymosan particles, phagocytosis, adhesion, and complement binding in macrophage cells. Mol Cells (2003) 16:216-23.

54. Rotsch J, Rohrbeck A, May M, Kolbe T, Hagemann S, Schelle I, et al. Inhibition of macrophage migration by C. botulinum exoenzyme C3. Naunyn Schmiedebergs Arch Pharmacol (2012) 385:883-90. doi:10.1007/s00210-012-0764-9
55. Tautzenberger A, Förtsch C, Zwerger C, Dmochewitz L, Kreja L, Ignatius A, et al. C3 Rho-inhibitor for targeted pharmacological manipulation of osteoclast-like cells. PLoS One (2013) 8:e85695. doi:10.1371/journal.pone.0085695

56. Barth H, Hofmann F, Olenik C, Just I, Aktories K. The N-terminal part of the enzyme component (C2I) of the binary Clostridium botulinum $\mathrm{C} 2$ toxin interacts with the binding component $\mathrm{C} 2 \mathrm{II}$ and functions as a carrier system for a Rho ADP-ribosylating C3-like fusion toxin. Infect Immun (1998) 66:1364-9.

57. Aktories K, Jung M, Böhmer J, Fritz G, Vandekerckhove J, Just I. Studies on the active site structure of C3-like exoenzymes: involvement of glutamic acid in catalysis of ADP-ribosylation. Biochimie (1995) 77:326-32. doi:10.1016/0300-9084(96)88142-9

58. Christow H, Lillich M, Sold A, Fahrer J, Barth H. Recombinant streptavidin-C3bot for delivery of proteins into macrophages. Toxicon (2013) 75:144-7. doi:10.1016/j. toxicon.2013.02.002

59. Lillich M, Chen X, Weil T, Barth H, Fahrer J. Streptavidin-conjugated C3 protein mediates the delivery of mono-biotinylated RNAse A into macrophages. Bioconjug Chem (2012) 23:1426-36. doi:10.1021/bc300041z

60. Collier RJ. Understanding the mode of action of diphtheria toxin: a perspective on progress during the 20th century. Toxicon (2001) 39:1793-803. doi:10.1016/ S0041-0101(01)00165-9

61. Ng DYW, Fahrer J, Wu Y, Kuan SL, Barth H, Weil T. Supramolecular dendronized streptavidin nanocarriers: a versatile and synergistic strategy for the delivery of therapeutically active proteins into human cells. Adv Healthc Mater (2013) 2:1620-9. doi:10.1002/adhm.201200419

62. Kuan S, Ng D, Wu Y, Förtsch C, Barth H, Doroshenko M, et al. pH responsive Janus-like supramolecular fusion proteins for functional protein delivery. J Am Chem Soc (2013) 135:17254-7. doi:10.1021/ja4084122

Conflict of Interest Statement: The authors declare that the research was conducted in the absence of any commercial or financial relationships that could be construed as a potential conflict of interest.

Copyright (c) 2015 Barth, Fischer, Möglich and Förtsch. This is an open-access article distributed under the terms of the Creative Commons Attribution License (CC BY). The use, distribution or reproduction in other forums is permitted, provided the original author(s) or licensor are credited and that the original publication in this journal is cited, in accordance with accepted academic practice. No use, distribution or reproduction is permitted which does not comply with these terms. 